Gut, 1969, 10, 497-501

\title{
Measurement of deoxyribonucleic acid (DNA) in canine jejunal fistular fluid ${ }^{1}$
}

\author{
DALE P. J. GOLDSMITH \\ From the Department of Biochemistry, University of Nebraska College of Medicine, USA
}

The epithelium of the gastrointestinal tract is one of the most rapidly regenerating tissues of the body. Cells divide in the mucosal pits and crypts, migrate to the surface, and desquamate into the lumen. This process proceeds at such a rate that the whole epithelium is replaced every few days (Lipkin, 1965). The rate of cell desquamation can be inferred from the rate of mitotic activity or studied by radioautographic techniques. The first of these methods requires that the desquamation rate be related directly to mitotic activity, a condition which may not always be true (Quastler, 1963). The second is a somewhat lengthy procedure not well adapted to investigation of short-term changes in desquamation rate.

Recently Croft, Pollock, and Coghill (1966) reported on gastric studies in which they related the rate of appearance of deoxyribonucleic acid (DNA) in stomach washings to gastric mucosal desquamation rate. This appears justifiable since all human somatic cell nuclei contain the same amount of DNA. Provided no cells other than epithelial cells get into the gastric fluid and no DNA is destroyed, the DNA in a timed collection of washings should be directly proportional to the number of cells shed into the gastric lumen during the interval studied.

We have now become interested in applying this method for evaluating the desquamation rate to the small intestine. Intestinal fluid is a complex mixture, however, and the literature gives ample evidence that extraneous substances in tissues or body fluids may interfere with DNA assay procedures (Volkin and Cohn, 1954; Croft and Lubran, 1965). It seemed important to us, therefore, to demonstrate that the DNA in intestinal fluid can be measured selectively and quantitatively. This report presents the results of our studies on this problem.

Since the presence of bile, pancreatic secretions or food in the intestinal lumen would complicate the assay procedures unnecessarily, these materials were eliminated by using secretions plus appropriate

'Supported by grants GB 2128 and GB 3033 from the National Science Foundation. washings from jejunal fistulas in dogs. The cold trichloroacetic acid (TCA) precipitation method employed in estimating gastric DNA by Croft and Lubran (1965) was applied to these secretions and washings. In certain cases pure DNA was added to the secretions and washings before adding trichloroacetic acid in order to determine the completeness of precipitation. The precipitates obtained were analysed for DNA by several methods and the values were compared. The results indicate that DNA can be assayed satisfactorily by each of the methods tried. This opens the way for possible evaluation of desquamation rate in the intestine by analysis of the DNA in the luminal fluid.

\section{METHODS}

COLLECTION OF FLUID AND GENERAL PROCEDURES In one set of experiments designed to study the assay for DNA, intestinal secretions from dual jejunal Thiry-Vella fistulas in a $\operatorname{dog}^{2}$ were collected by drainage in ice-cooled tubes for four hours. Each hour the fistulas were washed out gently with $0.9 \% \mathrm{NaCl}$ to facilitate removal of desquamated cells. The combined secretions and washings (approximately $250 \mathrm{ml}$ ) were treated with $20 \mathrm{ml}$ of $0.2 \mathrm{M}$ EDTA of $p \mathrm{H} 8.0$, homogenized well in a glass homogenizer with a teflon pestle, and diluted to $400 \mathrm{ml}$ with $0.9 \% \mathrm{NaCl}$. The diluted homogenate was then divided into $50 \mathrm{ml}$ portions. To each portion was added $0.075 \mathrm{ml}$ albumin solution containing $30 \mathrm{~g}$ bovine albumin in $100 \mathrm{ml}$ distilled water, and $5 \mathrm{ml}$ of $50 \%$ Trichloroacetic acid. All portions were stored at $-16^{\circ} \mathrm{C}$ for seven days ${ }^{3}$ and thawed, centrifuged, and the residues washed with $5 \%$ TCA as described by Croft and Lubran (1965). Each residue was dehydrated with acetone, dried, and weighed (approximate weight, $110 \mathrm{mg}$ ). Aliquots of these were taken for assay by the three procedures described below.

In a second set of experiments designed to study the recovery of DNA another four-hour sample of intestinal secretions and washings was collected from the same dog. The sample was treated with EDTA, homogenized, diluted to $400 \mathrm{ml}$ with $0.9 \% \mathrm{NaCl}$, and divided into eight $50 \mathrm{ml}$ portions. To four of the portions was added 'Two fistulas of the jejunum, each about $15 \mathrm{~cm}$ long, were placed side by side in the animal.

${ }^{3}$ The amount of DNA recovered was the same if the samples were allowed to stand for one day or for seven days at $-16^{\circ} \mathrm{C}$. 
$5.0 \mathrm{ml}$ of an aqueous solution of purified DNA containing $200 \mu \mathrm{g} / \mathrm{ml}$. Each of these was mixed well, and all portions were then treated with albumin and $50 \%$ TCA as described previously. They were stored at $-16^{\circ} \mathrm{C}$ for seven days and the precipitates converted to acetonedried residues as described above. Aliquots of these acetone-dried residues were taken for assay by the three procedures described below. When these precipitates were assayed, one fortified with DNA was evaluated together with one not fortified with DNA, and the difference between the two assay values was taken as the amount of added DNA recovered.

The methods of assay are shown in Figure 1. Nucleic acids were extracted from acetone-dried residues with hot TCA, and the extracts were reacted with diphenylamine or indole and assayed colorimetrically. In other experiments the residues were heated with hot $\mathrm{KOH}$ to destroy RNA, the DNA was precipitated from the cooled reaction mixtures with acid, and the precipitates were assayed spectrophotometrically in the ultra violet region.

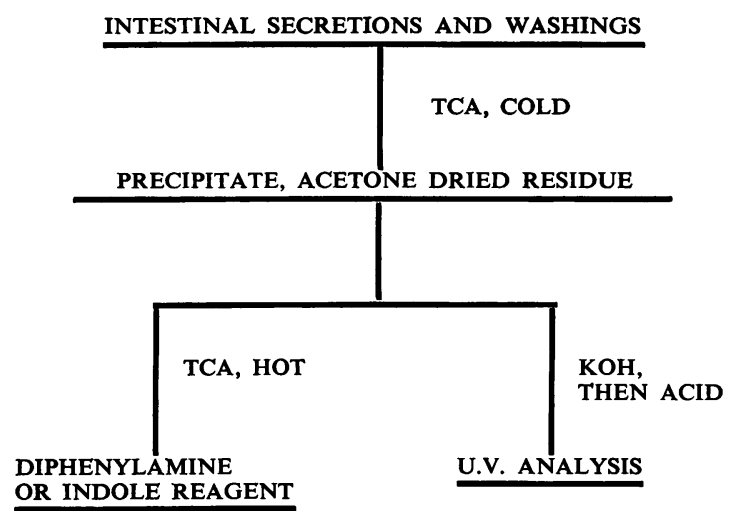

FIG. 1. Methods of assay.

ASSAY WITH DIPHENYLAMINE REAGENT Acetone-dried residue, $15 \mathrm{mg}$, was extracted with hot $5 \%$ TCA (total volume $7 \mathrm{ml}$ ) and a $2 \mathrm{ml}$ aliquot was reacted with diphenylamine reagent as described by Croft and Lubran (1965). The reaction mixture was allowed to stand at 6 to $13^{\circ} \mathrm{C}$ for 48 to 54 hours, and the concentration of DNA was then calculated from the absorbance at $600 \mathrm{~m} \mu$.

ASSAY WITH INDOLE REAGENT A modification of the method of Miller, Segal, and Harrington (1961) was employed. About $15 \mathrm{mg}$ of acetone-dried residue was extracted with $6 \mathrm{ml}$ of $10 \% \mathrm{TCA}$ at $100^{\circ} \mathrm{C}$ for 10 minutes. This was cooled and centrifuged. The supernatant fluid was decanted, and the solid was extracted a second time with $2 \mathrm{ml}$ of $10 \%$ trichloroacetic acid. This was also cooled and centrifuged. The second supernatant fluid was combined with the first. The combined fluids were diluted to $9 \mathrm{ml}$ with $10 \%$ TCA and a $3 \mathrm{ml}$ aliquot was taken for assay. Standard solutions were prepared containing 0 (blank), 20, 60, 100, and $200 \mu \mathrm{g}$ purified DNA 4 in $2 \mathrm{ml}$ of $10 \%$ trichloroacetic acid. These were heated for 10 minutes at $100^{\circ} \mathrm{C}$ and diluted to $3 \mathrm{ml}$ with $10 \%$ trichloroacetic acid. To each $3 \mathrm{ml}$ sample and standard was added $1.5 \mathrm{ml}$ of aqueous $0.04 \%$ indole solution and $1.5 \mathrm{ml}$ of concentrated $\mathrm{HCl}$. Each mixture was then heated at $100^{\circ} \mathrm{C}$ for 10 minutes, cooled to room temperature, and shaken with an equal volume of thiophenefree benzene (Mallinckrodt). After the benzene layer had separated, it was removed and discarded. Benzene extractions were continued until the benzene no longer became red. All assay solutions were then put in colorimeter tubes and allowed to stand in the refrigerator overnight. The next day the tubes were warmed to room temperature without shaking, and the concentration of DNA in each was calculated from the absorbance at $490 \mathrm{~m} \mu$. It was found desirable to let the solutions stand in the colorimeter tubes overnight in order to have them cleared completely of benzene.

SPECTROPHOTOMETRIC ASSAY An aliquot of acetonedried residue, $40 \mathrm{mg}$, was washed twice with $3 \mathrm{ml}$ of a $\mathrm{CHCl}_{3}-\mathrm{MeOH}$ mixture $(1: 1)$ and dried under nitrogen. The solid was digested with $1 \mathrm{~N} \mathrm{KOH}$ and the DNA and proteins were precipitated with alcohol and acetic acid according to the procedures of Kleinschmidt and Manthey (1958). The precipitate was extracted with $4.5 \mathrm{ml}$ of $4 \%$ $\mathrm{HC10}_{4}$ at $95^{\circ} \mathrm{C}$ for 15 minutes. The extract was cooled to room temperature and centrifuged. The supernatant fluid was decanted. The residue was extracted a second time with $1.5 \mathrm{ml}$ of $4 \% \mathrm{HClO}_{4}$, and the extract was again cooled and centrifuged. The second supernatant fluid was combined with the first. Standards were prepared by heating 0 (blank), 50,100,200, and $300 \mu \mathrm{g}$ samples of purified $\mathrm{DNA}^{4}$ in $6 \mathrm{ml}_{4} \% \mathrm{HClO}_{4}$ at $95^{\circ} \mathrm{C}$ for 15 minutes. The concentration of DNA in each sample was calculated from the absorbance at $268 \mathrm{~m} \mu$. Absorbance was also measured at $280 \mathrm{~m} \mu$ and $232 \mathrm{~m} \mu$ to determine the degree of freedom from impurities.

\section{RESULTS}

DIPHENYLAMINE REAGENT Representative absorption spectra of the reaction products of pure DNA with diphenylamine and of DNA from intestinal fluid with the same reagent are shown in Figure 2. The curves are similar. The $600: 550$ ratios are 1.84 and 1.85 respectively, and there is little evidence of interference by sialic acid in the spectrum of the sample from intestinal fluid.

ULTRAVIOLET SPECTROSCOPY The absorption spectra in the ultraviolet region for standard DNA and for a sample of DNA from mucosal secretions and washings are shown in Figure 3. Maximum absorbance was obtained at $268 \mathrm{~m} \mu$ with a minimum at $228 \mathrm{~m} \mu$. In some samples the minimum was shifted to higher wave lengths lowering the $268 / 228$ ratio.

'Deoxyribosenucleic acid, Na salt, highly polymerized, A grade Calbiochem. 


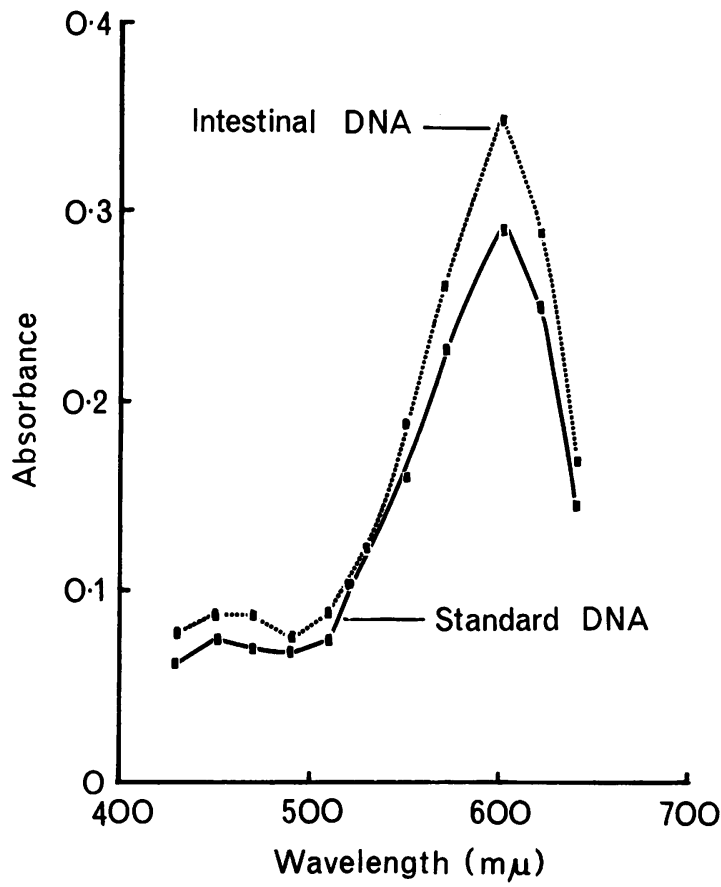

FIG. 2 .

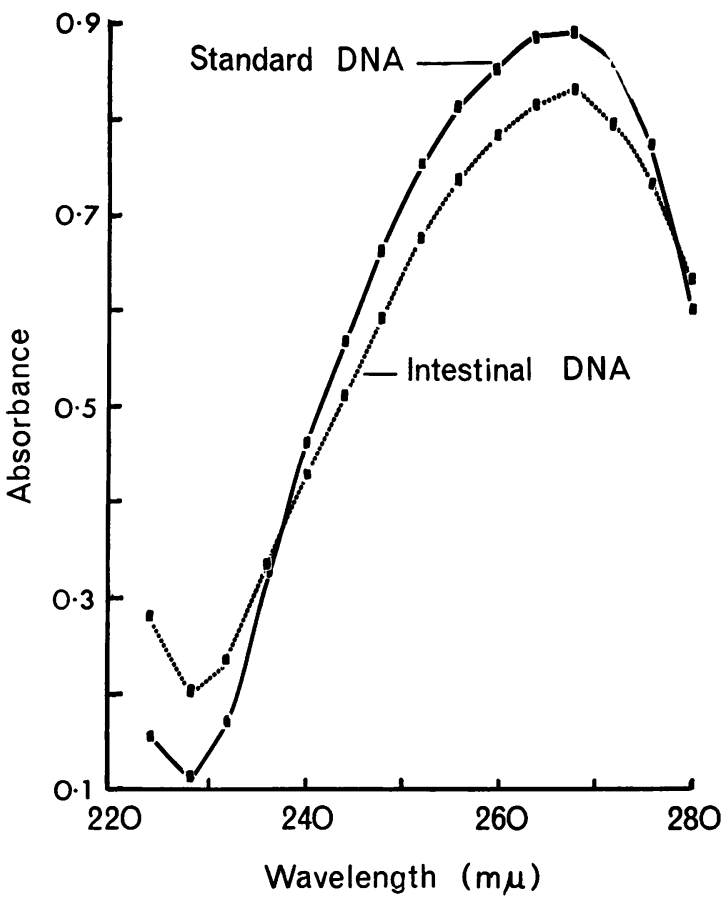

FIG. 3.

FIG. 2. Absorption spectra of the reaction products of pure DNA with diphenylamine and of DNA from intestinal fluid with the same reagent.

FIG. 3. Absorption spectra in the ultraviolet region for standard DNA and for a sample of DNA from mucosal secretions and washings.

The 280/268 ratio usually was not greatly affected. Extracting the DNA into $\mathrm{NaI}$ before hydrolysis with KOH (Noach, Bunk, and Wijling, 1962) did not eliminate this problem entirely and caused large losses of DNA. Normally this shift in minimum absorbance did not cause much error in the assay for DNA if the calculation of DNA concentration was based on absorbance at $268 \mathrm{~m} \mu$.

COMPARISON OF ASSAY METHODS The control samples to which no extra DNA had been added in the second set of experiments showed no difference in assay value by any of the three assay methods from samples of the first set of experiments. Consequently, the assay values for unfortified acetone-dried residues from the second collection were combined with values from the first collection for comparison purposes. The combined averages with standard errors are shown in the column 'DNA content' of Table I. There is reasonable agreement between the individual values obtained with any one assay method, the greatest dispersion values being found
TABLE I

DNA IN INTESTINAL SECRETIONS AND WASHINGS AND RECOVERY OF ADDED DNA

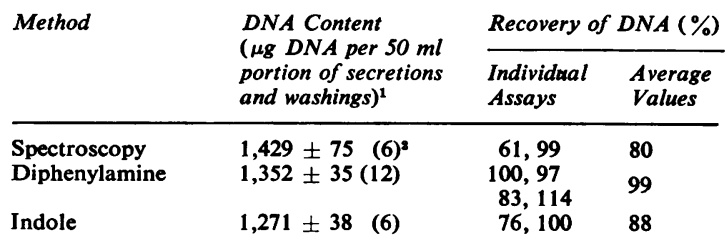

${ }^{1}$ Mean \pm standard error.

${ }^{2}$ Numbers in parentheses are number of acetone-dried residues assayed.

in the spectrophotometric method. If one relatively high figure is excluded from values obtained for the diphenylamine method, the remaining 11 values fall within $13 \%$ of one another. There is also close agreement between the average values obtained by the three methods. None of the differences between them is significant at the $5 \%$ level when evaluated by the test. 
RECOVERY OF DNA Four acetone-dried residues to which $1,000 \mu \mathrm{g}$ DNA had been added were assayed by the diphenylamine method, two were evaluated by the indole method, and two by ultraviolet spectroscopy. In each case the assay value of a control acetone-dried residue evaluated at the same time was subtracted from the DNA content of the fortified sample to give the amount of DNA recovered. The percentage of added DNA recovered in each of the eight assays, as well as the average recovery value for each assay procedure, are shown in Table I. Recovery was greater than $80 \%$ in all cases except two and averaged $99 \%$ with the diphenylamine reagent.

In order to test for possible loss of DNA in the precipitation of intestinal secretions and washings with cold $\left(-16^{\circ} \mathrm{C}\right.$, seven days) TCA, the supernatants from several such precipitations were reacted with diphenylamine reagent. A maximum of 10 to $15 \%$ DNA remained in solution if absorbance at 600 $\mathrm{m} \mu$ were used for the calculation. However, the absorption spectra of these samples were very poor, and it is doubtful if the calculations had meaning. When purified DNA was allowed to stand with intestinal juice in the refrigerator for six hours, there was no apparent destruction of the DNA.

\section{DISCUSSION}

The methods of assay employed in this study depend on the physical and chemical properties of several different components of the DNA molecule. Deoxypentose and purine deoxypentoses obtained by hydrolysis of the DNA in the TCA extract react selectively with diphenylamine, while purine deoxyribonucleotides react with indole. Hot $\mathrm{KOH}$ hydrolyses RNA quantitatively to mononucleotides while leaving the DNA relatively intact. When the $\mathrm{KOH}$ solution is cooled and acidified, the DNA and proteins precipitate while the ribonucleotides remain in solution. The DNA can then be extracted away from the proteins with hot perchloric acid and assayed spectrophotometrically in the ultraviolet region. The absorption is due to the purine and pyrimidine bases present in the DNA. Although these assay methods are relatively specific for DNA, they are not absolutely specific with every type of biological mixture. Among substances that are known to interfere with the DNA assay are sialic acid in the diphenylamine method (Croft and Lubran, 1965) and proteins, flavins, and TCA in the spectrophotometric method. Also, it is possible that the hot TCA extraction may hydrolyse deoxyribonucleotides and disturb assay by the indole method (Miller, Segal, and Harrington, 1961). It was for these reasons that the three methods of assay were compared.
The fact that the three methods gave essentially the same results (Table I) strongly suggests that they were all measuring only DNA, and that interference by other substances was minimal. This is substantiated by the fact that recovery of added DNA was quite high in most cases. Also, the ultraviolet absorption spectrum of the DNA from the intestine and the spectrum of its diphenylamine reaction product were similar to corresponding spectra of pure DNA. The relatively low variability in assay values, the generally high recovery of added DNA, and the absence of appreciable amounts of DNA in the 'mother liquors' from the cold TCA precipitations suggest that these measurements for DNA were also fairly quantitative. All three of the assay methods therefore seem useful, although the diphenylamine method appears most generally convenient and accurate.

The hot TCA used in the extraction procedure did not appear to degrade the DNA to a great extent. The assay values with indole reagent, however, were about $10 \%$ higher and appeared somewhat less variable if the standard DNA was heated with TCA before reaction with indole to simulate extraction conditions, rather than if it was not heated. The shift in the wavelength of the minimum absorbance in the ultraviolet region in some samples may have been due to different types or amounts of hydrolytic products formed. More probably it was due to the presence of a contaminant, perhaps protein.

As indicated in the introduction, the purpose of this investigation was to provide a means of measuring the desquamation rate of intestinal mucosal epithelium. The results of the study indicate that DNA can be analysed satisfactorily in 'pure' intestinal fluid. Other factors, such as the source of this DNA, whether it all arises from mucosal epithelial cells or whether much of it comes from bacterial cells or lymphocytes, must still be investigated before the method can be used practically for the purpose in mind. These problems are now being considered.

\section{SUMMARY}

The assay of DNA in intestinal fluid has been studied for its possible use in the evaluation of the desquamation rate of intestinal epithelium. Crude DNA was precipitated from identical aliquots of canine jejunal fistular secretions and washings by TCA at $-16^{\circ} \mathrm{C}$ and the precipitates were assayed by reaction with diphenylamine reagent, by reaction with indole reagent, and by absorption spectroscopy. The three methods gave similar values for the DNA content of all aliquots. Assay by the same three methods of 
samples of intestinal fluid to which pure DNA had been added before TCA precipitation showed 80 to $99 \%$ recovery of the added DNA. The absorption spectrum obtained after reaction of intestinal DNA with diphenylamine reagent was essentially the same as with pure DNA, as was the spectrum of the intestinal DNA itself in the ultraviolet region. The results suggest that DNA in intestinal fluid can be evaluated specifically and quantitatively.

\section{REFERENCES}

Croft, D. N., and Lubran, M. (1965). The estimation of deoxyribonucleic acid in the presence of sialic acid: application to analysis of human gastric washings. Biochem. J., 95, 612-620.
Croft, D. N., Pollock, D. J., and Coghill, N. F. (1966). Cell loss from human gastric mucosa measured by the estimation of deoxyribonucleic acid (DNA) in gastric washings. Gut, 7, 333-343.

Kleinschmidt, W. J., and Manthey, J. A. (1958). Quantitative determination of nucleic acids in whole tissue by paper chromatography. Arch. Biochem., 73, 52-64.

Lipkin, M. (1965). Cell proliferation in the gastrointestinal tract of man. Fed. Proc., 24, 10-15.

Miller, L. L., Segal, H. L., and Harrington, P. A. (1961). A method for measurement of urinary deoxyribonuclease based on the reaction of indole with deoxyribonucleotides, Proc. Soc. exp. Biol. (N.Y.), 106, 270-275.

Noach, E. L., Joosting Bunk, J., and Wijling, A. (1962). Influence of electroshock and phenobarbital on nucleic acid content of rat brain cortex. Acta physiol. pharmacol, 11, 54-69.

Quastler, H. (1963). Effects of irradiation on intestinal mucosal cell population. Fed. Proc., 22, 1330-1333.

Volkin, E., and Cohn, W. E. (1954). Estimation of nucleic acids. Meth. biochem. Anal., I, 287-305.

\section{The May 1969 Issue}

\section{THE MAY 1969 ISSUE CONTAINS THE FOLLOWING PAPERS}

\section{Signposts}

Tropical sprue JOHN G. BANWELL and SHERWOOD L. GORBACH

Bacteria and the aetiology of cancer of the large bowel VIVIENNE ARIES, J. S. CROWTHER, B. S. DRASAR, M. J. HILL and R. E. O. WILLIAMS

Postmortem survey of diverticular disease of the colon L. E. HUGHES

Part I Diverticulosis and diverticulitis

Part II The muscular abnormality in the sigmoid colon

Organization of the muscular wall of the human colon J. L. PACE and IFOR WILLIAMS

Relationship of anaemia and hypoproteinaemia to the functional and structural changes in the small bowel in hookworm disease B. N. TANDON, A. K. SARAYA, K. RAMACHANDRAN, and S. K. SAMA

Gastroenterostomy and vagotomy for chronic duodenal ulcer A. W. DELLIPIANI, I. B. MACLEOD, J. W. W. THOMSON, and A. A. SHIVAS
Evaluation and simple modification of the gastrin test M. C. MASON and G. R. GILES

Studies on the $G$ cells of the pyloric mucosa, the probable site of gastrin secretion E. SOLCIA, G. VASSALLO, and C. CAPELLA

Pyogenic liver abscess T. J. BUTLER and C. F. MCCARTHY

The origin of faecal fat H. S. WIGGINS, KATHRYN E. HOWELL, T. D. KELLOCK, and J. STALDER

Evidence for the release of gastric fibrinolytic activity into peripheral blood H. T. COX, L. POLLER, and JEAN M. THOMSON

Use of cuprous thiocyanate as a short-term continuous marker for faeces MATTHEW DICK

Proceedings of the British Society of Gastroenterology

Notes and activities

Copies are still available and may be obtained from the PUBLISHING MANAGER, BRITISH MEDICAL ASSOCIATION, TAVISTOCK SQUARE, W.c.1. price 17s. 6D. 